\title{
Plant growth and foliar characteristics of faba bean (Vicia faba L.) as affected by indole-acetic acid under water-sufficient and water-deficient conditions
}

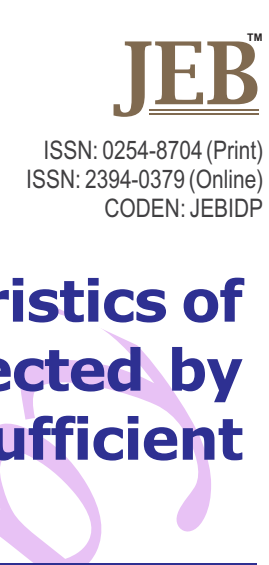

JEB Journal of

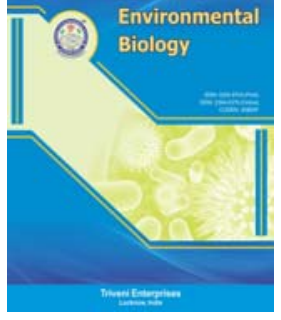

Authors Info

A. Husen ${ }^{1}$, M. Iqbal ${ }^{2 *}$ and I.M. Aref ${ }^{3}$

${ }^{1}$ Department of Biology, College of Natural and Computational Sciences, University of Gondar, P.O. Box 196, Gondar, Ethiopia

${ }^{2}$ Department of Botany, Faculty of Science, Jamia Hamdard, Hamdard Nagar, New Delhi-110 062, India

${ }^{3}$ Department of Plant Production, College of Food and Agricultural Sciences, King Saud University, P.O. Box 2460, Riyadh,

Saudi Arabia

${ }^{*}$ Corresponding Author Email : iqbalg5@yahoo.co.in

Key words

Drought stress,

IAA application,

Net photosynthetic rate,

PSIl efficiency,

Water status

Publication Info

Paper received: 21.01.2016

Revised received: 26. 04.2016

Re-revised received: 29.07.2016

Accepted: 13.09.2016

\section{Abstract}

Aim: As water is crucial for survival, growth and yield of plants, it is highly desirable to devise strategies for enhancing drought tolerance in plants. This study investigates the impact of foliar application of indole acetic acid (IAA) on plant growth and leaf characteristics of faba bean (Vicia faba L.) under normal and water-deficit conditions in order to determine its role in drought resistance of plants.

Methodology: In a pot experiment, 4-week-old seedlings were sprayed daily with IAA (0, 15, 30 and $\left.45 \mathrm{mg} \mathrm{l}^{-1}\right)$ for 15 days. These seedlings were then maintained under (a) regular watering with $100 \%$ field capacity, and (b) water stress created by stopping watering for 5 days. Fifty-day-old seedlings were sampled for analyzing the growth, water content and photosynthetic parameters by standard methods.

Results: Water-deficit condition reduced plant growth, dry mass production, pigment concentration, maximum quantum yield of PSII (Fv/Fm), stomatal conductance ( $g s)$, net photosynthetic rate $(P n)$, transpiration rate $(E)$ and relative water content (RWC). IAA application enabled the plants to withstand water stress and reduced the expected loss by about $18 \%$ in root length, $7 \%$ in shoot length, $10 \%$ in basal stem diameter, $11 \%$ in number of branches, $3 \%$ in number of leaves, $20 \%$ in leaf length, $22 \%$ in leaf area, $48 \%$ in root dry mass, $34 \%$ in stem dry mass and $26 \%$ in leaf dry mass. The loss was also mitigated by $44 \%$ in chl a, $39 \%$ in chl $b, 60 \%$ in carotenoids, $9 \%$ in $\mathrm{Fv} / \mathrm{Fm}, 36 \%$ in $\mathrm{gs}, 63 \%$ in $\mathrm{Pn}, 35 \%$ in $E$ and $52 \%$ in RWC of the leaf.

Interpretation: Water-deficit hindered the vegetative growth of seedlings by affecting adversely the dry-mass production, photosynthetic pigments, gaseous exchange, photochemical efficiency and water status of plants, while IAA application promoted these parameters not only in normal but also in waterstressed conditions. The $45 \mathrm{mg} \mathrm{IAAl}^{-1}$ dose proved to be most effective.

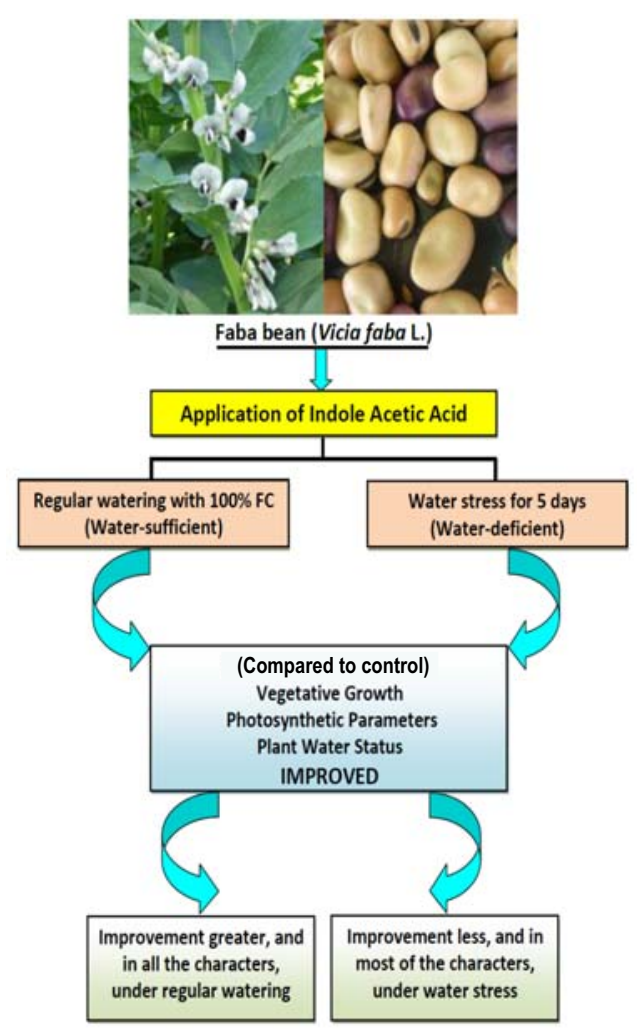




\section{Introduction}

Under drought and/or salinity stress, crop plants face difficulty in uptaking water from soil due to increased osmotic pressure of soil solution. Many parts of the world do not have enough water for crop irrigation, and the global climate change is likely to aggravate the situation further (Ezra, 2001; Elliott et al., 2014). Given this, efforts are being made to develop crop varieties that have a limited water requirement and can thrive well in drought-prone areas.

Water stress induces a variety of morphological, physiological, biochemical and molecular changes in plants, which hamper the basic plant functions such as photosynthesis, cell division and cell expansion, leading ultimately to growth inhibition and reduced yield (Aref et al., 2013; Husen et al., 2014). Reduction in soil water availability leads to a low plant water potential causing loss of turgidity and expansion of cells in the leaves. Plants tend to avoid excessive transpiration by closing the stomata, which reduces the gaseous exchange between leaf and the atmosphere, leading to a low intercellular $\mathrm{CO}_{2}$ concentration (Flexas et al., 2004), reduced diffusion of $\mathrm{CO}_{2}$ to chloroplasts and a limited net $\mathrm{CO}_{2}$-assimilation rate (Chaves et al., 2002), with ensuing negative feedback in photochemical efficiency. Water stress also affects leaf-area expansion, absorption of photosynthetically active radiation and leaf efficiency to carry out carbon fixation (Flexas et al., 2004). However, plants exhibit adaptive cellular responses like up-regulation of oxidative-stress protectors and accumulation of protective solutes, besides leaf area adjustments that reduce water loss by transpiration (Anjum et al., 2008, 2012). Efficiency of photosystem II (PSII), measured as chlorophyll fluorescence (maximum quantum yield $F v / F m$ ), has been used extensively as a diagnostic tool in various studies of the impact of environmental stress on the metabolic performance of plant species (Husen, 2010) and hence, as an indicator of seedling-stock quality (Husen, 2009; Hanachi et al., 2014) Reduction in the quantum yield of photosystem is influenced not only by light intensity, but also by superimposition of other environmental stresses such as high temperature, salinity, water availability or $\mathrm{CO}_{2}$ supply (Souza et al., 2004; Husen et al., 2016). Water stress inhibits photosynthetic activity in tissues due to imbalance between the receipt and utilization of light (Foyer and Noctor, 2009). To cope with these conditions, plants develop several strategies to avoid photoinhibitory processes.

Plant hormones help the plants adapt to changing environments, by mediating plant growth and development, nutrient allocation and source/sink transitions. Cross talk between different plant hormones results in synergetic/antagonic interactions that are crucial in determining plant responses to abiotic stress (Peleg and Blumwald, 2011). Indole acetic acid (IAA), a naturally occurring auxin, has been successfully used to improve many cash crops (Kaya et al., 2010; Husen et al., 2016).
It enhances sucrose concentration by stimulating the photoassimilate transport to and within the developing wheat grains (Darussalam et al., 1998), and confers tolerance to plants against water and salt stress (Ashraf et al., 2006; Kaya et al., 2010,). Genes associated with auxin-signalling pathways are stimulated when plants are exposed to abiotic stresses (Coupe et al., 2006).

Ethiopia second to China in faba bean production, is considered as one of the nine major agro-geographical regions for production of crops including faba bean (Husen et al., 2012). High yield, small seeds, less anti-nutritional factors and high adaptation ability to modern agriculture has made this plant more attractive for farmers and for the feed- and food-manufacturing industries. While growing in the drought-prone parts of Ethiopia (Ezra, 2001), faba bean has to suffer from water stress. IAA application is likely to compensate the deleterious effects of this stress. In light of the above the present study was undertaken to investigate the IAA-induced changes in plant growth, leaf characteristics, water status and physiological activities of Vicia faba L. grown under water-stress in order to find out whether IAA application can nullify or reduce the adverse effects of water stress.

\section{Materials and Methods}

Experimental site : Experiments were conducted in the Botanical Science Research Laboratory (Department of Biology) at the Tewodros campus of the University of Gondar. During the entire experimental period, relative humidity was $50 \%$, the maximum and minimum daily temperature was recorded as $29 \pm$ 1 and $18 \pm 1^{\circ} \mathrm{C}$, respectively, and no rainfall was observed.

Plant material and pot media : Seeds of faba bean (Vicia faba L. cultivar Dosha), obtained from Gondar Agricultural Research Centre, Gondar (Ethiopia), were surface-sterilized with $80 \%$ ethanol for $15 \mathrm{~min}$, followed by repeated washing with distilled water. Clean seeds were then sown in a plastic tray containing $75 \%$ soil and $25 \%$ farmyard manure (FYM). Watering was done regularly. After 2 weeks of germination, selected uniform seedlings were transferred to plastic pots ( $8 \mathrm{~cm}$ width $\times 16 \mathrm{~cm}$ height) filled with $1.5 \mathrm{~kg}$ soil and $500 \mathrm{~g}$ FYM in $3: 1$ ratio, sown at a depth of $2 \mathrm{~cm}$ and irrigated regularly with tap water with $100 \%$ field capacity for the next 2 weeks, supposedly a period of plant acclimatization. The soil in pots was sandy loam $(62.56 \%$ sand, $14.88 \%$ clay and $22.56 \%$ silt), with $\mathrm{pH} 7.23$ and $\mathrm{EC}$ was $0.68 \mathrm{~ms} \mathrm{~cm}^{-1}$.

Experimental design, IAA application and water deficit treatment : After acclimatization, pots were divided into 8 groups to assess the role of IAA and water stress condition, singly and in combination (Table 1). The pots were arranged in a simple randomized design. Each pot contained one seedling only. Prior to the commencement of water stress, foliar spray of IAA $(0,15$, 30 and $\left.45 \mathrm{mg} \mathrm{l}^{-1}\right)$ was done daily for 15 days. Thereafter, two water-supply regimes, namely, (a) regular watering with $100 \%$ FC 
Table 1: Scheme of IAAapplication and watering schedule

\begin{tabular}{|c|c|}
\hline Treatment name & IAA and watering treatment \\
\hline $\mathrm{T} 1$ & Regular watering with $100 \%$ field capacity $+00 \mathrm{mg} \mathrm{IAAI}^{-1}$ (Control) \\
\hline T2 & Regular watering with $100 \%$ field capacity $+15 \mathrm{mg} \mathrm{IAAI}^{-1}$ \\
\hline T3 & Regular watering with $100 \%$ field capacity $+30 \mathrm{mg} \mid \mathrm{AAl}^{-1}$ \\
\hline T4 & Regular watering with $100 \%$ field capacity $+45 \mathrm{mg} \mathrm{IAAI}^{-1}$ \\
\hline T5 & No watering for 5 days $+00{\mathrm{mg}|A A|^{-1}}^{-1}$ \\
\hline T6 & No watering for 5 days $+15{\mathrm{mg}|\mathrm{AA}|^{-1}}^{-1}$ \\
\hline $\mathrm{T7}$ & 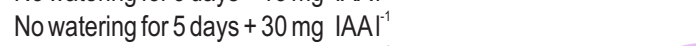 \\
\hline T8 & 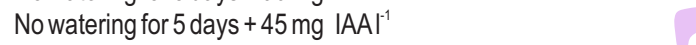 \\
\hline
\end{tabular}

and (b) withholding irrigation up to 5 days leading to incipient wilting, were applied. Details of irrigation and IAA application to different plant lots are given in Table 1. Five replications, each of three plants, were prepared for each treatment (T1 to T8). Sampling was done when plants were 50-day old.

Plant growth and leaf characteristics : Plant growth parameters and leaf traits were measured for each treatment. The seedlings were uprooted gently for recoding the length of root and shoot $(\mathrm{cm})$, number of branches, and the size, area and number of opened leaves. Ground-line basal diameter $(\mathrm{mm})$ of stem was measured with electronic digital caliper. The length $(\mathrm{mm})$ and area $\left(\mathrm{mm}^{2}\right)$ of individual leaves were measured using a leaf area meter (ADC Bio Scientific Limited, U.K.). To obtain the dry mass of different plant parts, the roots, stems and leaves were separated, dried in a hot air oven (at $85^{\circ} \mathrm{C}$ ) and weighed on an electronic digital balance (Citizen Scale, CY510, Poland) till a constant weight was obtained. Five replications were used for determining each of these parameters.

Concentration of photosynthetic pigments : Samples collected on the fifth day after each treatment were analyzed for photosynthetic pigments; 3 samples from each of 5 replications were used. Following the method of Hiscox and Israelstam (1979), test tubes containing $0.5 \mathrm{~g}$ of chopped leaf immersed in $7 \mathrm{ml}$ of dimethyl sulfoxide (DMSO) were kept in oven at $65^{\circ} \mathrm{C}$ for $2 \mathrm{hr}$. To the chlorophyll extract, thus obtained for each sample, DMSO was added further to make the volume of aliquot as $10 \mathrm{ml}$. Of this, $3 \mathrm{ml}$ extract was transferred to disposable polystyrene cuvettes and optical density (OD) was recorded at 663 and 645 $\mathrm{nm}$ (for chlorophyll) and at 510 and $480 \mathrm{~nm}$ (for carotenoid), using a T60 UVIVIS spectrophotometer (PG Instruments Limited, England). The chlorophylls ( $a \& b$ ) and carotenoid contents were estimated by the formulae given by Duxbury and Yentsch (1956) and MacLachlan and Zalick (1963).

Chlorophyll fluorescence : Chlorophyll fluorescence was analyzed for leaves from each treatment in the forenoon (10 to 11 a.m.) using a portable Multi-Mode Chlorophyll Fluorometer (OptiSciences, Inc., USA). Prior to fluorescence measurements, the upper surface of the leaf was pre-darkened with leaf clips for 30 min to ensure complete relaxation of all reaction centres. The basal non-variable chlorophyll fluorescence $(F o)$, maximal fluorescence induction $(F m)$ and variable fluorescence $(F v)$ were determined. Photochemical efficiency of PSII (the maximum quantum yield $=F v(F m)$ was calculated following Genty et al. (1989); the maximum PSIl efficiency (Fv/Fm) was estimated by the following equation:

$$
F v / F m=(F m-F o) / F m
$$

Foliar gas exchange and water status : Leaf gas exchange was measured between 10 to 11 a.m. for each treatment. Stomatal conductance $(g s)$, net photosynthetic rate $(P n)$ and transpiration rate $(E)$ were measured using a portable leaf gas exchange system (ADC BioScientific Limited, U.K.) on fully expanded attached leaves. The equipment was used with the following specifications/adjustments: leaf surface area $6.25 \mathrm{~cm}^{2}$, ambient $\mathrm{CO}_{2}$ concentration $\left(\mathrm{C}_{\text {ref }}\right) 371 \mu \mathrm{mol} \mathrm{mol}^{-1}$, temperature of leaf chamber (Tch) 25 to $28^{\circ} \mathrm{C}$, molar air flow per $\mathrm{m}^{2}$ of leaf surface (Us) $296 \mathrm{~mol} \mathrm{~m}^{-2} \mathrm{~s}^{-1}$, leaf chamber volume gas flow rate (v) $400 \mathrm{ml}$ $\mathrm{m}^{-1}$, ambient pressure $(P) 97.95 \mathrm{kPa}, P A R\left(Q_{\text {leat }}\right)$ at leaf surface up to $770 \mu \mathrm{mol} \mathrm{m} \mathrm{m}^{-2} \mathrm{~s}^{-1}$. Water status of leaf was determined for each treatment (T1-T8) in fully developed leaves by measuring the relative water content (RWC). Leaf samples were weighed immediately after harvest, to obtain fresh weight (FW) and then kept overnight in distilled water at $5^{\circ} \mathrm{C}$ in dark, before obtaining their turgid weight (TW). The material was then oven-dried at $80^{\circ} \mathrm{C}$ for $12 \mathrm{hr}$ for estimation of dry weight (DW). Relative water content (RWC) was then calculated from these values.

Calculation and statistical analysis : In order to know the relative change in different parameters due to water stress, and water stress + IAA application, percent variation at T5 (no watering for 5 days; no IAA) and T8 (no watering for 5 days; $45 \mathrm{mg}$ $\mathrm{IAAL}^{-1}$ ) from control (T1: regular watering; no IAA) was calculated. SPSS software version 16.0 (SPSS Inc., Illinois, USA) was used for statistical analysis of the data obtained, which were further subjected to one-way ANOVA to determine the significant difference among the treatments. Means were compared by using the Duncan test at significance level $P<0.05$.

\section{Results and Discussion}

The effects of IAA application on certain growth parameters of root, stem and leaves of $V$. faba plants grown under 
water-sufficient (T1) and water-deficient (T2) conditions are presented in Tables 2 and 3, respectively. Under water-sufficient condition, the root and shoot lengths increased significantly with all IAA concentrations as compared to control (T1: regular watering but no IAA application). The maximum response was recorded at the highest concentration (45 $\mathrm{mg} \mathrm{IAAl}^{-1}$ ), i.e., at T4, showing about $6 \%$ and $4 \%$ increase in root and shoot lengths, respectively, with reference to control (T1) (Table 2). Basal stem diameter, number of branches and number of leaves also increased slightly, showing non-significant variations from the control. Increase in the length and area of the leaf was, however, significant with $3 \%$ and $0.76 \%$ gain over the control respectively (Table 2).

Water deficit had a negative impact on all the above parameters, whereas application of IAA concentrations on waterdeficient population showed an ameliorative effect. The root and shoot lengths increased significantly with all IAA treatments under water stress. The maximum impact appeared in T8 (water deficit + $45 \mathrm{mg} \mathrm{IAAl}^{-1}$ ) as compared to T5 (water deficit + no IAA). In terms of percentage, T8 population gained in root and shoot lengths by $18 \%$ and $7 \%$ respectively over $T 5$, the water-deficient population. Basal stem diameter, number of branches, and number of leaves also increased, but with a non-significant difference. However, the increase in leaf length and leaf area in T8 population was significant, with $20 \%$ and $22 \%$ variation from T5 respectively (Table 3). A comparison of water-sufficient and water-deficient populations demonstrated that the roots and shoots were significantly shorter under short-term water stress (T5), showing a $20 \%$ and $16 \%$ variation, respectively, from $\mathrm{T} 1$ that had a regular watering (Fig. 1). The values for basal stem diameter, number of branches and number of leaves were low under water stress, showing non-significant variations from T1, the water-sufficient population. Reduction in leaf length and leaf area was significant under water stress (T5) with $16 \%$ and $20 \%$ variation from T1, respectively (Fig. 1). IAA treatment had some favorable effect on plant growth parameters even in water-

Table 2 : Impact of IAA application on plant growth and leaf characteristics in water-sufficient population of Vicia faba

\begin{tabular}{lllll}
\hline Growth and leaf parameters & \multicolumn{1}{c}{$\mathrm{T} 1$} & \multicolumn{1}{c}{$\mathrm{T} 2$} & $\mathrm{~T}$ & $\mathrm{~T}$ \\
\hline Root length $(\mathrm{cm})$ & $32.12 \pm 1.15^{\mathrm{bcd}}$ & $33.14 \pm 1.12^{\mathrm{cd}}(3.18)$ & $33.67 \pm 1.17^{\mathrm{d}}(4.83)$ & $34.17 \pm 1.18^{\mathrm{d}}(6.38)$ \\
Shoot length $(\mathrm{cm})$ & $35.92 \pm 3.52^{\mathrm{bc}}$ & $36.90 \pm 1.64^{\mathrm{d}}(2.73)$ & $37.61 \pm 1.86^{\mathrm{d}}(4.70)$ & $37.51 \pm 2.96^{\mathrm{d}}(4.43)$ \\
Stem base diameter $(\mathrm{mm})$ & $7.46 \pm 0.42$ & $7.46 \pm 0.68(0.00)$ & $7.48 \pm 0.62(0.27)$ & $7.48 \pm 0.47(0.27)$ \\
Number of branches & $3.85 \pm 0.28$ & $3.85 \pm 0.23(0.00)$ & $3.86 \pm 0.34(0.26)$ & $3.86 \pm 0.33(0.26)$ \\
Number of leaves & $71.50 \pm 3.63$ & $70.81 \pm 3.52(0.96)$ & $71.85 \pm 4.42(0.49)$ & $71.89 \pm 5.67(0.54)$ \\
Leaflength $\left(\mathrm{mm}^{\mathrm{c}}\right)$ & $176.23 \pm 5.91^{\mathrm{b}}$ & $178.43 \pm 8.51^{\mathrm{b}}(1.25)$ & $178.59 \pm 7.25^{\mathrm{b}}(1.34)$ & $181.47 \pm 2.23^{\mathrm{c}}(2.97)$ \\
Leaf area $\left(\mathrm{mm}^{2}\right)$ & $15350.10 \pm 277.39^{\mathrm{b}}$ & $15460.37 \pm 143.06^{\mathrm{c}}(0.72)$ & $15462.56 \pm 159.27^{\mathrm{c}}(0.73)$ & $15467.65 \pm 185.39^{\mathrm{c}}(0.76)$ \\
\hline
\end{tabular}

Values followed by the same letter indicate no significant differences at $P<0.05$ level according to the Duncan test. Each value represents the mean $\pm S E$ of five replicates. Values within parenthesis are percent variation obtained for T2, T3 and T4 treatments in relation to T1

Table 3 : Impact of IAAapplication on plant growth and leaf characteristics in water-deficient population of Vicia faba

\begin{tabular}{lllll}
\hline Growth and leaf parameters & \multicolumn{1}{c}{ T5 } & \multicolumn{1}{c}{ T6 } & \multicolumn{1}{c}{ T7 } & \multicolumn{1}{c}{ T8 } \\
\hline Root length $(\mathrm{cm})$ & $25.60 \pm 2.10^{\mathrm{a}}$ & $29.40 \pm 1.14^{\mathrm{b}}(14.84)$ & $30.12 \pm 1.02^{\mathrm{bc}}(17.66)$ & $30.18 \pm 1.01^{\mathrm{bc}}(17.89)$ \\
Shoot length $(\mathrm{cm})$ & $30.31 \pm 1.98^{\mathrm{a}}$ & $31.51 \pm 2.56^{\mathrm{a}}(3.96)$ & $32.70 \pm 2.52^{\mathrm{ab}}(7.88)$ & $32.50 \pm 2.92^{\mathrm{ab}}(7.22)$ \\
Stem base diameter $(\mathrm{mm})$ & $6.77 \pm 0.45$ & $7.44 \pm 1.01(9.89)$ & $7.47 \pm 1.10(10.33)$ & $7.47 \pm 1.39(10.33)$ \\
Number of branches & $3.21 \pm 0.31$ & $3.25 \pm 0.27(1.25)$ & $3.26 \pm 0.31(1.56)$ & $3.57 \pm 0.61(11.21)$ \\
Number of leaves & $68.41 \pm 3.76$ & $70.65 \pm 4.71(3.27)$ & $70.71 \pm 3.88(3.36)$ & $70.82 \pm 4.43(3.52)$ \\
Leaflength $(\mathrm{mm})$ & $148.23 \pm 8.74^{\mathrm{a}}$ & $176.85 \pm 5.43^{\mathrm{b}}(19.31)$ & $177.54 \pm 7.56^{\mathrm{b}}(19.77)$ & $178.74 \pm 6.24^{\mathrm{b}}(20.58)$ \\
Leaf area $\left(\mathrm{mm}^{2}\right)$ & $\left.12218.23 \pm 339.04^{\mathrm{a}}\right)$ & $14893.42 \pm 275.03^{\mathrm{b}}(21.89)$ & $14932.72 \pm 284.94^{\mathrm{b}}(22.22)$ & $14935.86 \pm 269.39^{\mathrm{b}}(22.24)$ \\
\hline
\end{tabular}

Values followed by the same letter indicate no significant differences at $P<0.05$ level according to the Duncan test. Each value represents the mean $\pm S E$ of five replicates. Values within parenthesis are percent variation obtained for T6, T7 and T8 treatments in relation to T5

Table 4 : Impact of IAAapplication on dry mass production of different plant parts in water-sufficient population of Vicia faba

\begin{tabular}{lccll}
\hline Dry mass $(\mathbf{g})$ & $\mathrm{T} 1$ & $\mathrm{~T} 2$ & $\mathrm{~T}$ & $\mathrm{~T}$ \\
\hline Roots & $0.47 \pm 0.12^{\mathrm{b}}$ & $0.50 \pm 0.08^{\mathrm{b}}(6.38)$ & $0.51 \pm 0.11^{\mathrm{b}}(8.51)$ & $0.52 \pm 0.03^{\mathrm{c}}(10.64)$ \\
Stem & $1.76 \pm 0.81^{\mathrm{b}}$ & $1.84 \pm 0.66^{\mathrm{bc}}(4.55)$ & $1.87 \pm 0.72^{\mathrm{bc}}(6.25)$ & $1.88 \pm 0.25^{\mathrm{c}}(6.82)$ \\
Leaves & $1.61 \pm 0.27^{\mathrm{b}}$ & $1.68 \pm 0.24^{\mathrm{c}}(4.35)$ & $1.78 \pm 0.06^{\mathrm{c}}(10.56)$ & $1.79 \pm 0.08^{\mathrm{d}}(11.18)$ \\
\hline
\end{tabular}

Values followed by the same letter indicate no significant differences at $P<0.05$ level according to the Duncan test. Each value represents the mean $\pm S E$ of three replicates. Values within parenthesis are percent variation and obtained for T2, T3 and T4 treatments in relation to T1 


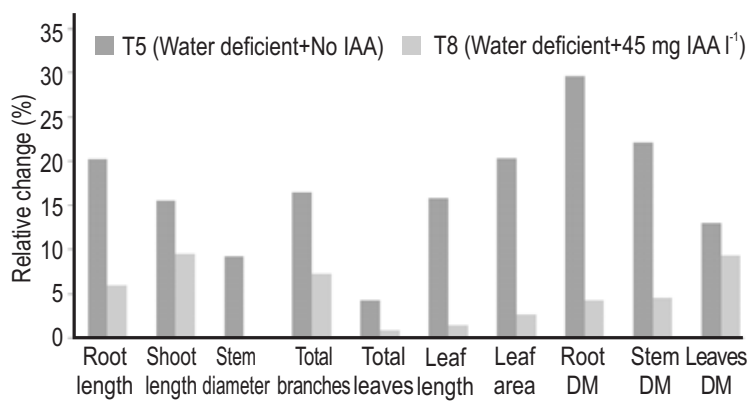

Fig. 1: Relative change in terms of percentage in various growth and biomass parameters of Vicia faba as obtained for $T 5$ and $T 8$ in relation to T1 (control). T5: (No watering for 5 days + No IAA); T8: (No watering for 5 days + 45 $\mathrm{mg} \mathrm{IAA}^{-1}$ ); T1: (Regular watering + No IAA)

deficient plants. Therefore, when compared with T1, the loss in root length $(6 \%)$, shoot length $(9 \%)$, basal stem diameter $(0.13 \%)$, number of branches $(7 \%)$, number of leaves $(0.95 \%)$, leaf length (1\%) and leaf area (3\%) was lower in T8 (water stress + $45 \mathrm{mg} \mathrm{IAAl}^{-1}$ ) than in T5 (water stress + no IAA treatment) plants (Fig. 1).

Adequate water supply is essential for a plant to complete its life cycle with optimum growth and productivity. Growth parameters, water status, photosynthetic pigments and physiological responses are important in screening plants for

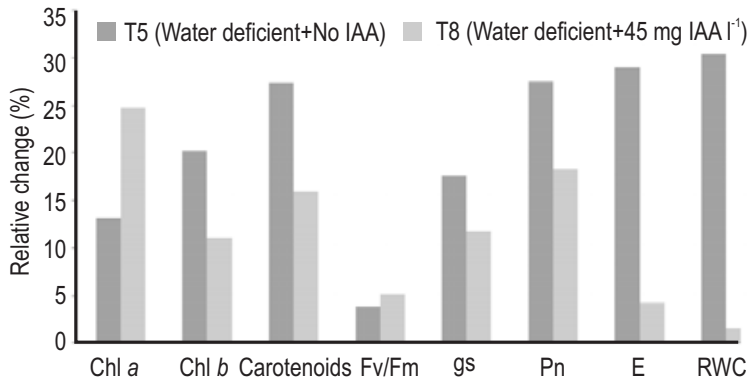

Fig. 2: Relative change in terms of percentage in some photosynthesisrelated parameters of Vicia faba as obtained for T5 and T8 in relation to T1 (control). T5: (No watering for 5 days + No IAA); T8: (No watering for 5 days + 45mg IAAl $\left.\right|^{-1}$ ); T1: (Regular watering + No IAA); Fv/Fm: maximum quantum yield of PSII; gs: stomatal conductance; $\mathrm{Pn}$ : net photosynthetic rate; E: transpiration rate, and RWC: relative water content)

tolerance to water stress. The reduction in root length, shoot length, leaf length and leaf area of faba bean under water-deficit condition might involve suppression of cell expansion/cell growth due to low turgor pressure, as discussed by Jaleel et al. (2008). Decreased leaf area affects the ultimate yield due to limited capacity of photosynthesis (Ge et al., 2012). Even a short-term water-deficit may cause significant loss in terms of plant growth and final yield (Aref et al., 2013; Husen et al., 2014). Reduction in dry mass under water stress could be due to limited leaf

Table 5: Impact of IAAapplication on dry mass production of different plant parts in water-deficient population of Vicia faba

\begin{tabular}{lcccc}
\hline Dry mass $(\mathbf{g})$ & T5 & T6 & T7 & T8 \\
\hline Roots & $0.33 \pm 0.09^{\mathrm{a}}$ & $0.48 \pm 0.12^{\mathrm{b}}(45.45)$ & $0.49 \pm 0.03^{\mathrm{b}}(48.48)$ & $0.49 \pm 0.04^{\mathrm{b}}(48.48)$ \\
Stem & $1.37 \pm 0.16^{\mathrm{a}}$ & $1.81 \pm 0.17^{\mathrm{b}}(32.12)$ & $1.83 \pm 0.23^{\mathrm{bc}}(33.58)$ & $1.84 \pm 0.11^{\mathrm{bc}}(34.31)$ \\
Leaves & $1.40 \pm 0.07^{\mathrm{a}}$ & $1.67 \pm 0.08^{\mathrm{c}}(19.29)$ & $1.75 \pm 0.09^{\mathrm{c}}(25.00)$ & $1.76 \pm 0.09^{\mathrm{c}}(25.71)$ \\
\hline
\end{tabular}

Values followed by the same letter indicate no significant differences at $P<0.05$ level according to the Duncan test. Each value represents the mean $\pm S E$ of five replicates. Values within parenthesis are percent variation obtained for $T 6, T 7$ and $T 8$ treatments in relation to $T 5$

Table 6: Impact of IAAapplication on photosynthetic pigments in water-sufficient population of Vicia faba

\begin{tabular}{lllll}
\hline Photosynthetic pigments & T1 & T2 & T3 & T4 \\
\hline Chlorophyll a (mg g $^{-1}$ f. wt.) & $0.463 \pm 0.007^{\mathrm{b}}$ & $0.467 \pm 0.003^{\mathrm{b}}(0.86)$ & $0.580 \pm 0.003^{\mathrm{c}}(25.27)$ & $0.581 \pm 0.006^{\mathrm{c}}(25.49)$ \\
Chlorophyll $b$ (mg g ${ }^{-1}$ f. wt.) & $0.515 \pm 0.009^{\mathrm{bc}}$ & $0.538 \pm 0.013^{\mathrm{bc}}(4.47)$ & $0.568 \pm 0.015^{\mathrm{bc}}(10.29)$ & $0.588 \pm 0.008^{\mathrm{c}}(14.17)$ \\
Carotenoids (mg ( $^{-1}$ f. wt.) & $0.684 \pm 0.005^{\mathrm{b}}$ & $0.698 \pm 0.012^{\mathrm{b}}(2.05)$ & $0.842 \pm 0.010^{\mathrm{c}}(23.10)$ & $0.871 \pm 0.017^{\mathrm{c}}(27.34)$ \\
\hline
\end{tabular}

Values followed by the same letter indicate no significant differences at $\mathrm{P}<0.05$ level according to the Duncan test. Each value represents the mean $\pm S E$ of three replicates. Values within parenthesis are percent variation and obtained for T2, T3 and T4 treatments in relation to T1

Table 7 : Impact of IAAapplication on photosynthetic pigments and in water- deficient population of Vicia faba

\begin{tabular}{|c|c|c|c|c|}
\hline Photosynthetic pigments & T5 & T6 & $\mathrm{T7}$ & T8 \\
\hline Chlorophyll a (mg g ${ }^{-1}$ f. wt.) & $0.402 \pm 0.008^{\mathrm{a}}$ & $0.413 \pm 0.004^{b}(2.74)$ & $0.469 \pm 0.018^{b}(16.67)$ & $0.578 \pm 0.012^{c}(43.78)$ \\
\hline Chlorophyll b (mg g ${ }^{-1}$ f. wt.) & $0.411 \pm 0.008^{a}$ & $0.451 \pm 0.015^{\mathrm{bc}}(9.73)$ & $0.542 \pm 0.012^{b c}(31.87)$ & $0.572 \pm 0.017^{\mathrm{bc}}(39.17)$ \\
\hline Carotenoids (mg g ${ }^{-1}$ f. wt.) & $0.496 \pm 0.013^{\mathrm{a}}$ & $0.683 \pm 0.016^{b}(37.70)$ & $0.788 \pm 0.017^{\circ}(58.87)$ & $0.793 \pm 0.009^{\circ}(59.88)$ \\
\hline
\end{tabular}

Values followed by the same letter indicate no significant differences at $P<0.05$ level according to the Duncan test. Each value represents the mean $\pm S E$ of five replicates. Values within parenthesis are percent variation obtained for $\mathrm{T} 6, \mathrm{~T} 7$ and $\mathrm{T} 8$ treatments in relation to $\mathrm{T} 5$ 
Table 8: Impact of IAA application on physiological characteristics of leaves in water-sufficient population of Vicia faba

\begin{tabular}{lllll}
\hline Physiological activities & T1 & T2 & T3 & T4 \\
\hline Maximum quantum yield of PSIII $(F v / F m)$ & $0.751 \pm 0.010^{\mathrm{b}}$ & $0.783 \pm 0.013^{\mathrm{c}}(4.26)$ & $0.796 \pm 0.009^{\mathrm{d}}(5.99)$ & $0.798 \pm 0.006^{\mathrm{e}}(6.26)$ \\
Stomatal conductance $\left(\mathrm{mol} \mathrm{m}^{-2} \mathrm{~s}^{-1}\right)$ & $0.034 \pm 0.003^{\mathrm{b}}$ & $0.034 \pm 0.002^{\mathrm{b}}(0.00)$ & $0.036 \pm 0.002^{\mathrm{d}}(5.88)$ & $0.045 \pm 0.002^{\mathrm{e}}(32.25)$ \\
Net photosynthetic rate $\left(\mu \mathrm{mol} \mathrm{CO}_{2} \mathrm{~m}^{-2} \mathrm{~s}^{-1}\right)$ & $6.70 \pm 0.68^{\mathrm{b}}$ & $7.86 \pm 0.94^{\mathrm{b}}(17.31)$ & $8.21 \pm 0.22^{\mathrm{c}}(22.54)$ & $8.26 \pm 0.31^{(}(23.28)$ \\
Transpiration rate $\left(\mathrm{mmol} \mathrm{m} \mathrm{s}^{-1}\right)$ & $1.86 \pm 0.09^{\mathrm{b}}$ & $2.16 \pm 0.04^{\mathrm{b}}(16.13)$ & $2.44 \pm 0.04^{\mathrm{d}}(31.18)$ & $2.48 \pm 0.07^{\mathrm{d}}(33.33)$ \\
Relative water content $(\%)$ & $79.76 \pm 1.94^{\mathrm{bc}}$ & $81.59 \pm 2.15^{\mathrm{cdd}}(2.29)$ & $83.21 \pm 2.63^{\mathrm{d}}(4.33)$ & $85.23 \pm 1.05^{\mathrm{e}}(6.86)$ \\
\hline
\end{tabular}

Values followed by the same letter indicate no significant differences at $P<0.05$ level according to the Duncan test. Each value represents the mean $\pm S E$ of three replicates. Values within parenthesis are percent variation and obtained for T2, T3 and T4 treatments in relation to T1

Table 9 : Impact of IAA application on physiological characteristics of leaves in water-deficient population of Vicia faba

\begin{tabular}{lllll}
\hline Physiological activities & T5 & T6 & T7 & T8 \\
\hline Maximum quantum yield of PSII $(F v / F m)$ & $0.722 \pm 0.011^{\mathrm{a}}$ & $0.773 \pm 0.017^{\mathrm{c}}(7.06)$ & $0.789 \pm 0.006^{\mathrm{d}}(9.20)$ & $0.790 \pm 0.010^{\mathrm{a}}(9.42)$ \\
Stomatal conductance $\left(\mathrm{mol} \mathrm{m}^{-2} \mathrm{~s}^{-1}\right)$ & $0.028 \pm 0.003^{\mathrm{a}}$ & $0.031 \pm 0.002^{\mathrm{a}}(10.71)$ & $0.035 \pm 0.003^{\mathrm{b}}(25.00)$ & $0.038 \pm 0.0031^{\mathrm{c}}(35.71)$ \\
Net photosynthetic rate $\left(\mu \mathrm{mol} \mathrm{CO}_{2} \mathrm{~m}^{-2} \mathrm{~s}^{-1}\right)$ & $4.85 \pm 0.76^{\mathrm{a}}$ & $6.92 \pm 0.81^{\mathrm{b}}(42.68)$ & $7.91 \pm 0.56^{\mathrm{b}}(63.09)$ & $7.93 \pm 0.51^{\mathrm{b}}(63.50)$ \\
Transpiration rate $\left(\mathrm{mmol} \mathrm{m} \mathrm{s}^{-1} \mathrm{~s}^{-1}\right)$ & $1.32 \pm 0.05^{\mathrm{a}}$ & $1.41 \pm 0.07^{\mathrm{a}}(6.82)$ & $1.66 \pm 0.07^{\mathrm{b}}(25.76)$ & $1.78 \pm 0.09^{\mathrm{b}}(34.85)$ \\
Relative water content $(\%)$ & $53.38 \pm 2.27^{\mathrm{a}}$ & $78.04 \pm 2.82^{\mathrm{b}}(46.20)$ & $80.21 \pm 2.42^{\text {bcd }}(50.26)$ & $81.10 \pm 2.31^{\text {bcd }}(51.93)$ \\
\hline
\end{tabular}

Values followed by the same letter indicate no significant differences at $\mathrm{P}<0.05$ level according to the Duncan test. Each value represents the mean $\pm S E$ of five replicates. Values within parenthesis are percent variation obtained for T6, T7 and T8 treatments in relation to T5

expansion. Low stomatal conductance leading to reduced carbon assimilation per unit leaf area ultimately results in low biomass production (Medrano et al., 2002).

IAA application induced favorable changes in dry mass production under water-sufficient condition (Table 4). Dry mass of roots, stem and leaves increased over control with all IAA concentrations, with T4 population showing highest gain. In terms of percentage, T4 population exceeded T1 population in dry mass production of roots, stem and leaves by about $11 \%, 7 \%$ and $11 \%$ respectively. Water deficit caused a significant suppressive effect on dry mass production, while IAA application caused stimulatory effects even under water-deficit in a dose-dependent manner (Table 5). The dry mass of roots, stem and leaves increased with all IAA concentrations, showing the maximum impact of $48 \%$, $34 \%$ and $26 \%$ respectively, in T8 (water deficit $+45 \mathrm{mg} \mathrm{IAAl}^{-1}$ ), as compared to T5 (water deficit + no IAA). Dry mass production was reduced under water stress by about $30 \%$ for roots, $22 \%$ for stem and $13 \%$ for leaves. Thus, foliar application of IAA in waterdeficient plants enhanced the dry mass of all plant parts, showing the maximum effect with $45 \mathrm{mg} \mathrm{IAA} \mathrm{I}^{-1}$. Consequently, in comparison to $\mathrm{T} 1$ (with regular watering), the reduction in dry mass production was less in T8 population (with $45 \mathrm{mg} \mathrm{IAA} \mathrm{I}^{-1}$ under water stress) than in T5 (water deficient and without IAA) population. Percent variation from T1 was only $4 \%$ in roots and stem and $9 \%$ in leaves (Fig. 1). IAAapplication increases biomass production possibly because auxins enhance the plant's ability to adapt to abiotic stresses by mediating a wide range of responses (Wolters and Jurgens, 2009).

IAA treatments caused a significant increase in the concentration of photosynthetic pigments in water-sufficient plants (Table 6). A $45 \mathrm{mg} \mathrm{l}^{-1}$ dose (T4) enhanced the chlorophyll a, chlorophyll $b$ and carotenoids contents of leaves maximally, i.e. by $25 \%, 14 \%$, and $27 \%$, respectively, as compared to control (T1). Pigment concentrations were considerably reduced under water stress (T5), but IAA application showed an ameliorative effect in water-deficient population also (Table 7). The maximum impact appeared in T8 population (with $45 \mathrm{mg} \mathrm{IAAI}^{-1}$ ), population, which showed about $44 \%, 39 \%$ and $60 \%$ increase in the contents of chl $a$, chl $b$ and carotenoids, respectively, with reference to $T 5$ (water stress + no IAA) (Table 7). The contents of these three pigments were reduced by $13 \%, 20 \%$ and $27 \%$ under water stress (T5), but increased by $25 \%, 11 \%$ and $16 \%$, respectively, due to IAA application to water-deficient population (T8) in comparison to T1 (Fig. 2). On the whole, the concentrations of photosynthetic pigments were higher in plants with normal watering than in those under water stress, as reported earlier also (Husen et al., 2014; Embiale et al., 2016). IAA application improved the situation, both in water-sufficient and water-deficient plants.

Application of IAA significantly promoted chlorophyll fluorescence $(F v / F m)$, stomatal conductance $(g s)$, net photosynthetic rate $(P n)$, transpiration rate $(E)$ and relative water content (RWC) of leaves in plants with regular watering schedule

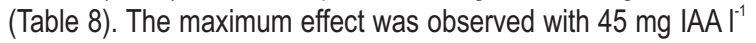
(T4). In terms of percentage, the Fv/Fm, gs, $\mathrm{Pn}, \mathrm{E}$ and RWC in T4 plants were enhanced by $6 \%, 32 \%, 23 \%, 33 \%$ and $7 \%$, respectively, as compared with $\mathrm{T} 1$. Water deficit decreased all these parameters in general. IAA treatment had a positive effect even under water stress (Table 9). These foliar parameters increased with all IAA concentrations, showing maximum impact with the highest concentration used. The maximum variation 
observed between T8 and T5 with reference to Fv/Fm, gs, Pn, E and RWC was nearly $9 \%, 36 \%, 63 \%, 35 \%$ and $52 \%$, respectively. Impact of water stress and IAA application on the above parameters have established the positive role of auxin on growth of $V$. faba plants both under normal and water-deficit conditions. Compared to the water-sufficient population (T1), Fv/Fm, gs, Pn, $E$ and RWC in water-deficient population (T5) declined by $4 \%$, $18 \%, 28 \%, 29 \%$ and $30 \%$, respectively (Fig. 2). The ameliorative effect of IAA treatment in water-deficient plants was apparent from higher values recorded for T6-T8 in comparison to T5. However, with reference to control (T1), variation in Fv/Fm, gs, $P n, E$ and RWC was about $5 \%, 12 \%, 18 \%, 4 \%$ and $2 \%$ respectively, under $45 \mathrm{mg}$ IAA treatment in water-deficient population (T8). The maximum quantum yield of PSII (Fv/Fm) ranged from 0.72 to 0.80 in control, stressed and IAA-treated plants. The $\mathrm{Fv} / \mathrm{Fm}$ value decreased slightly in water-deficit condition than under regular watering (Fig. 2), which is not unusual (Husen et al., 2014; Embiale et al., 2016). The minor changes observed in the $\mathrm{Fv} / \mathrm{Fm}$ value are in line with the evidence on resistance of PSII photochemistry against moderate drought (Živčák et al., 2014). However, the negative influence of drought on PSII activity was dependent on the stress duration and the genotypes used (Husen, 2010; Husen et al., 2014, 2016).

Usually, Fv/Fm in higher plants is around 0.83 (Bjorkman and Demmig, 1987). The photosystem II itself is not affected directly by water deficit unless water stress continues for too long (Baker and Rosenqvist, 2004). Since photosynthesis is the primary sink for energy derived from photochemistry, whereas photorespiration and nitrogen assimilation are relatively small sinks, especially in the developed leaves, a close relationship exists between the rate of $\mathrm{O}_{2}$ evolution from PSIl and the net rate of $\mathrm{CO}_{2}$ fixation (Edwards and Baker 1993; Santos et al., 2004). Stomatal closure under water-stress results in limiting the ambient $\mathrm{CO}_{2}$ diffusion to the mesophyll and hence, reduces photosynthesis (Varone et al., 2012). However, the primary PSII efficiency was not influenced by water stress (Lawlor and Cornic, 2002). On the other hand, the phenomena of $g s, P n$ and $E$ enhanced due to foliar spray of IAA, as reported earlier by Ashraf et al. (2006). Water deficit diminishes RWC of leaf in V. faba, but IAAapplication alleviated the adverse effect of water stress, being most effective at $45 \mathrm{mgl}^{-1}$ concentration.

In short, IAA application improved tolerance of plants as evident by enhanced vegetative growth, dry-mass production, photosynthetic pigments, gaseous exchange, photochemical efficiency and water status. The synergistic or antagonistic hormonal action and coordinated regulation of hormonebiosynthesis pathways play crucial roles in making plants adapt to abiotic stress (Wolters and Jurgens, 2009; Peleg and Blumwald, 2011).

In view of the limited water resources for agronomic use in Ethiopia and elsewhere, development of drought-tolerant lines has gained prime significance. Foliar spray of IAA on faba bean crop alleviated the adverse effects of water stress in the present study, suggesting that the loss of vegetative plant growth caused by disturbed metabolic activities due to water stress can be recovered by IAAapplication.

\section{Acknowledgments}

The authors thank the Gondar Agricultural Research Centre, Ethiopia for providing authentic faba bean seeds, and the Laboratory Assistant of Department of Biology, University of Gondar, for nursery assistance.

\section{References}

Anjum, N.A., I. Ahmad, M. Pacheco, A.C. Duarte, E. Pereira, S. Umar, A. Ahmad and M. Iqbal: Modulation of glutathione, its redox couple and related enzymes in plants under abiotic stresses. In: Oxidative Stress in Plants: Causes, Consequences and Tolerance (Eds.: N.A. Anjum, S. Umar and A. Ahmad) I.K. International Publishing House, New Delhi, India, pp. 467-498 (2012).

Anjum, N.A., S. Umar, M. Iqbal and N.A. Khan: Growth characteristics and antioxidant metabolism of moongbean genotypes differing in photosynthetic capacity subjected to water deficit stress. J. Plant Inter., 3, 127-136 (2008).

Aref, M.I., A.I. Ahmad, P.R. Khan, H. El-Atta and M. lqbal: Droughtinduced adaptive changes in the seedling anatomy of Acacia ehrenbergiana and Acacia tortilis subsp raddiana. Trees Struct. Func., 27, 959-971 (2013).

Ashraf, M.Y., N. Azhar and M. Hussain: Indole acetic acid (IAA) induced changes in growth, relative water contents and gas exchange attributes of barley (Hordeum vulgare L.) grown under water stress conditions. Plant Growth Regul., 50, 85-90 (2006).

Baker, N.R. and E. Rosenqvist: Applications of chlorophyll fluorescence can improve crop production strategies: an examination of future possibilities. J. Exp. Bot., 55, 1607-1621 (2004).

Bjorkman, O. and B. Demmig: Photon yield of $\mathrm{O}_{2}$ evolution and chlorophyll fluorescence characteristics at $77 \mathrm{~K}$ among vascular plants of diverse origins. Planta, 170, 489-504 (1987).

Chaves, M.M., J.S. Pereira, J. Maroco, M.L. Rodrigues, C.P.P. Ricardo, M.L. Osório, I. Carvalho, T. Faria and C. Pinheiro: How plants cope with water stress in the field. Photosynthesis and growth. Ann. Bot., 89, 907-916 (2002).

Coupe, S.A., B.G. Palmer, J.A. Lake, S.A. Overy, K. Oxborough, F.I. Woodward, J.E. Gray and W.P. Quick: Systemic signalling of environmental cues in Arabidopsis leaves. J. Exp. Bot., 57, 329341 (2006).

Darussalam, M.A. Cole and J.W. Patric: Control of photo assimilates transport to and within developing grains of wheat. Aust. J. Plant Physiol., 25, 69-77 (1998).

Duxbury, A.C. and C.S. Yentsch: Plankton pigment monographs. J. Mar. Res., 15, 19-101 (1956).

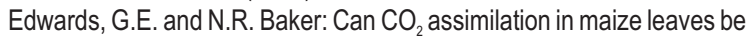
predicted accurately from chlorophyll fluorescence analysis? Photosynth. Res., 37, 89-102 (1993).

Elliott, J., D. Deryng, C. Müller, K. Frieler, M. Konzman, D. Gerten, M. Glotter, M. Flörke, Y. Wada, N. Best, S. Eisner, B.M. Fekete, C. Folberth, I. Foster, S.N. Gosling, I. Haddeland, N. Khabarov, F. 
Ludwig, Y. Masaki, S. Olin, C. Rosenzweig, A.C. Ruane, Y. Satoh, E. Schmid, T. Stacke, Q. Tang and D. Wisser: Constraints and potentials of future irrigation water availability on agricultural production under climate change. Proc. Nat. Acad. Sci., 111, 3239-3244 (2014)

Embiale, A., M. Hussein, A. Husen, S. Sahile and K. Mohammed: Differential sensitivity of Pisum sativum L. cultivars to water-deficit stress: Changes in growth, water status, chlorophyll fluorescence and gas exchange attributes. J. Agron., 15, 45-57 (2016).

Ezra, M.: Demographic responses to environmental stress in the drought- and famine-prone area of northern-Ethiopia. Int. J. Popul. Geogr., 7, 259-270 (2001).

Flexas, J.J., F. Bota, G. Loreto, G. Cornic and T.D. Sharkey: Diffusive and metabolic limitations to photosynthesis under drought and salinity in $\mathrm{C}_{3}$ plant. Plant Biol., 6, 269-279 (2004).

Foyer, C.H. and G. Noctor: Redox regulation in photosynthetic organisms: signaling, acclimation and practical implications. Antioxid. Redox Sign., 11, 861-905 (2009).

Ge, T., F. Sui, L. Bai, C. Tong and N. Sun: Effects of water stress on growth, biomass partitioning, and water-use efficiency in summer maize (Zea mays L.) throughout the growth cycle. Acta Physiol. Plant., 34, 1043-1053 (2012).

Genty, B., J.M. Briantais and N.R. Baker: The relationship between quantum yield of photosynthetic electron transport and quenching of chlorophyll fluorescence. Biochim. Biophys. Acta, 990, 87-92 (1989).

Hanachi, S., M.C. Van Labeke and T. Mehouachi: Application of chlorophyll fluorescence to screen eggplant (Solanum melongena L.) cultivars for salt tolerance. Photosynthetica, 52, 57-62 (2014).

Hiscox, J.D. and G.F. Israelstam: A method for the extraction of chlorophyll from leaf tissue without maceration. Can. J. Bot., $\mathbf{5 7}$, 1332-1334 (1979).

Husen, A.: Growth, chlorophyll fluorescence and biochemical markers in clonal ramets of shisham (Dalbergia sissoo Roxb.) at nursery stage. New For., 38, 117-129 (2009).

Husen, A.: Growth characteristics, physiological and metabolic responses of teak (Tectona grandis Linn.f.) clones differencing in rejuvenation capacity subjected to drought stress. Silvae Genet., 59, 124-136 (2010).

Husen, A., M. Iqbal and I.M. Aref: Growth, water status and leaf characteristics of Brassica carinata under drought and rehydration conditions. Braz. J. Bot., 37, 217-227 (2014).

Husen, A., M. Iqbal and I.M. Aref: IAA-induced alteration in growth and photosynthesis of pea (Pisum sativum L.) plants grown under salt stress. J. Environ. Biol., 37, 421-429 (2016).

Husen, A., V.K. Mishra, K. Semwal and D. Kumar: Biodiversity status in
Ethiopia and challenges. In: Environmental Pollution and Biodiversity (Eds.: K.P. Bharati, A. Chauhan and P. Kumar). Vol 1, Discovery Publishing House Pvt. Ltd., New Delhi, India, pp. 31-79 (2012).

Jaleel, C.A., P. Manivannan, G.M.A. Lakshmanan, M. Gomathinayagan and R. Panneersevam: Alteration in morphological parameters and photosynthetic pigment response of Catharanthus roseus under soil deficits. Colloid. Surf. B Bionterf., 61, 298-303 (2008).

Kaya, C., A.L. Tuna and A.M. Okant: Effect of foliar applied kinetin and indole acetic acid on maize plants grown under saline conditions. Turk. J. Agric. For., 34, 529-538 (2010).

Lawlor, D.W. and G. Cornic: Photosynthetic carbon assimilation and associated metabolism in relation to water deficits in higher plants. Plant Cell Environ., 25, 275-294 (2002).

MacLachlan, S. and S. Zalick: Plastid structures,nchlorophyll concentration and free amino acid composition of a chlorophyll mutant of barley. Can. J. Bot., 41, 1053-1060 (1963).

Medrano, H., J.M. Escalona, J. Bota, J. Gulías and J. Flexas: Regulation of photosynthesis of $\mathrm{C}_{3}$ plants in response to progressive drought: Stomatal conductance as a reference parameter. Ann. Bot., 89, 895-905 (2002).

Peleg, Z. and E. Blumwald: Hormone balance and abiotic stress tolerance in crop plants. Curr. Opin. Plant Biol., 14, 290-295 (2011).

Santos, M.G., R.V. Ribeiro, R.F. Oliveira and C. Pimentel: Gas exchange and yield response to foliar phosphorus application in Phaseolus vulgaris L. under drought. Braz. J. Plant Physiol., 16, 171-179 (2004).

Souza, R.P., E.C. Machado, J.A.B. Silva, A.M.M.A. Lagoa and J.A.G. Silveira: Photosynthetic gas exchange, chlorophyll fluorescence and some associated metabolic changes in cowpea (Vigna unguiculata) during water stress and recovery. Environ. Exp. Bot., 51, 45-56 (2004).

Varone, L., M. Ribas-Carbo, C. Cardona, A. Gallé, H. Medrano, L. Gratani and J. Flexas: Stomatal and non-stomatal limitations to photosynthesis in seedlings and saplings of Mediterranean species pre-conditioned and aged in nurseries: Different response to water stress. Environ. Exp. Bot., 75, 235-247 (2012).

Wolters, H. and G. Jurgens: Survival of the flexible: hormonal growth control and adaptation in plant development. Nature Rev. Gene., 10, 305-317 (2009).

Živčák, M., H.M. Kalaji, H.B. Shao, K. Olšovská and M. Brestič: Photosynthetic proton and electron transport in wheat leaves under prolonged moderate drought stress. J. Photochem. Photobiol. B, 137, 107-115 (2014). 